\title{
The Level of Student Career Center Management and Future Career Planning of Students Universitas Negeri Malang: A Descriptive Analysis
}

\author{
Maulana Amirul Adha ${ }^{1}$, Nova Syafira Ariyanti ${ }^{2}$, Maisyaroh $^{3}$, Imron Arifin ${ }^{4}$ \\ Department of Educational Management, Faculty of Education, Universitas Negeri Malang \\ Jalan Semarang 5 Malang, East Java, Indonesia \\ amirulmaulana1013@gmail.com¹,novasyafira@gmail.com², maisyaroh.fip@um.ac.id², \\ imron.arifin.fip@um.ac.id ${ }^{4}$
}

\begin{abstract}
Unemployment is one of the main problems in developing countries such as Indonesia. Total unemployment in Indonesia as a whole in the last three semesters has decreased, but ironically the unemployment of undergraduate graduates in the last three semesters has always increased. The purpose of this study is to determine the level of management student career centers, entrepreneurship personality, family environment, entrepreneurship education, entrepreneurship intention and future career planning of students Universitas Negeri Malang. The research method used a descriptive quantitative approach. The sampling technique used in each faculty is used proportional random sampling with a sample size of 381 students. The results of this study are, (1) the level of student career center management, entrepreneurship education and students future career planning is in the good category, (2) the level of student entrepreneurship personality, family environment and student entrepreneurship intention is in the very good category.
\end{abstract}

Keywords: future career, students career center, family environment, entrepreneurship education, entrepreneurship intention

\section{Introduction}

Nowadays, college graduates prioritize work as civil servant employee or work in a company, they forget that future career choices are not only that, but there is still a career as an entrepreneur. The problem of the high number of undergraduate unemployment in Indonesia is caused by many scholars when students become confused about what will be done after graduation [1]. It shows that aspiring graduates do not yet have a good career plan. Future career planning is important to be owned by the individual. Career planning is the process by which one selects career objectives and career path [2]. Career planning is an ongoing process of self-assessment followed by goal setting [3].

Students who have an intention in entrepreneurship are very important both as a backup for current entrepreneurs and as a springboard for future work [4], Especially for high-tech industries in developing countries such as Indonesia. Looking at the rapidly growing technological environment of the 4.0 Industrial Revolution era, it brings out business opportunities open to students. Entrepreneurship personality can foster entrepreneurship intention that later affects individual decisions to determine his future career [5]. Entrepreneurship development is a big challenge this era, it's a global community challenge [6]. The challenges are increasingly complex and there is an increase in competency of 
graduates from universities entering the industrial era of 4.0. It is important to understand the role of entrepreneurship competence and their characteristics and to determine how they influence the intention and career plan of student entrepreneurship [7].

To become a support entrepreneur as well as the role of family especially parents are needed by students [8]. In addition to support and family roles, entrepreneurship education is an important component that can give someone a boost in determining future career choices [9]. Universitas Negeri Malang (UM) as one of the largest universities in Indonesia, has a big role to improve the quality of Indonesian human resources. Colleges need to prepare graduates that can be employed, including with entrepreneurship skills [10].

Questions about alumni and students can be solved while the student career center is well managed [11]. The center of Career Development is expected to accelerate the association and prospective graduates with agencies or industries who need labor and can form the academic competence of both hard skills and soft skills needed primarily can form the personal character of students who needed to become entrepreneurs [4]. Successful people usually already have a mature career plan since early [12]. But career planning does not guarantee career success, attitudes, experiences, education, family support, and motivation also plays an important role in individual careers [7], [13].

Students who are currently running their studies in universities are expected to have an understanding of entrepreneurship. So with the understanding of its entrepreneurship, they are able to create new employment [13], [14]. The 4.0 Industrial revolution has encouraged the potential for the development of entrepreneurship activity as a result of increased use and application of technology, where there will be increased demand for skilled technological workforce [15]. In an entrepreneurship intention study from a college graduate in Malaysia, [7] also highlighted that promoting entrepreneurship is one way to address employment feasibility issues. The purpose of this study is to determine the level of management student career centers, entrepreneurship personality, family environment, entrepreneurship education, entrepreneurship intention and future career planning of students Universitas Negeri Malang.

\section{Method}

The descriptive quantitative approach was used in this study. The population of this study were students of Universitas Negeri Malang class of 2016. This is because not all UM students between semesters 1-4 have received courses or entrepreneurship education and also students of Class 2016 are currently in semester 8 so that soon they will become UM alumni. Proportional random sampling is a sampling technique that is used in each faculty with a sample size of respondents was 381 students. Research data collection instruments use closed poll through the use of Google forms media. Angket is developed based on the theories that lubricates research variables [16], [17]. Prior to data collection, research instruments conducted expert tests, as well as instrument validity and reliability tests. Analysis of data using descriptive analysis using the help of SPSS 24.0 program. 


\section{Results And Discussion}

\subsection{Implementation Of Student Career Center Management}

Thus the length of the interval class, frequency distribution and the percentage of Student Career Center Management level are set as in Table 1. Based on Table 1, it can be explained that a career center management variable obtained very good criteria with a percentage of $21.0 \%$, good at $53.0 \%$, good less at $22.1 \%$ as well as the not good criteria of $3.9 \%$. Based on the analysis of the data can be concluded, that the percentage of implementation level of the management of the Student Career Center Universitas Negeri Malang in the category of 'good', which is $53.0 \%$.

Table 1. Frequency Distribution of Student Career Center Management Implementation

\begin{tabular}{|c|c|c|c|c|}
\hline No & Category & Interval & Frequency & Percentage \\
\hline 1 & Very good & $129-158$ & 80 & $21.0 \%$ \\
\hline 2 & Good & $99-128$ & 202 & $53.0 \%$ \\
\hline 3 & Good less & $69-98$ & 84 & $22.1 \%$ \\
\hline 4 & Not good & $39-68$ & 15 & $3.9 \%$ \\
\hline \multicolumn{3}{|c|}{ Total } & 381 & $100.0 \%$ \\
\hline
\end{tabular}

The UM Student Career Center is managed by P2BK3A under LP3 UM [18]. A career center that is an institution or unit within a higher education structure that performs the function of bringing together students and job seekers graduates with Labor users [19]. The main role of a career development center is a unit in the university that provides support in the form of academic programs and experiential learning to encourage students to learn and develop themselves [20]. The Career center within a college has a function of bridging the needs of the world's working information required by universities as well as students [11] There are two important things to look out for by higher education institutions i.e. learning and career coaching as they are required for students to have a future picture that they run after graduation, so that they can plan their future careers [20].

\subsection{Students Entrepreneurship Personality}

Thus the length of the interval class, frequency distribution and percentage of the student entrepreneurship personality level are set as in Table 2. Based on Table 2, it can be explained that the student entrepreneurship personality level obtained very good criteria with a percentage of $54.1 \%$, good amounting to $42.8 \%$, good less at $2.3 \%$ as well as the not good criteria of $0.8 \%$. Based on the analysis of the data can be concluded, that the percentage of entrepreneurship personality of the students of the Universitas Negeri Malang in the category of 'excellent', which is $54.1 \%$.

Table 2. Frequency Distribution of Student Entrepreneurship Personality

\begin{tabular}{clccc}
\hline No & Category & Interval & Frequency & Percentage \\
\hline 1 & Very good & $143-176$ & 206 & $54.1 \%$ \\
2 & Good & $110-142$ & 163 & $42.8 \%$ \\
3 & Good less & $77-109$ & 9 & $2.3 \%$ \\
4 & Not good & $44-76$ & 3 & $0.8 \%$ \\
\hline \multicolumn{7}{r}{ Total } & 381 & $100.0 \%$ \\
\hline \multicolumn{7}{r}{} & &
\end{tabular}


Based on the research results it is known that the entrepreneurship personality level of UM students is in very good category. Entrepreneurship personality are behaviors and entrepreneurship attitudes demonstrated by the attitudes, characters and character of one who has a willingness to bring innovative ideas into the real world creatively [21], [22]. To acquire such abilities, one must have an entrepreneurship personality, namely [23]: (1) Being able to self-drive, (2) confident, (3) Action-oriented, (4) energetic, and (5) tolerant of uncertainty.

\subsection{Students Family Environment}

Thus the length of the interval class, frequency distribution and percentage of student family environment are defined as in Table 3. Based on Table 3. can be explained that the student family environment level obtained very good criteria with a percentage of $54.6 \%$, good at $36.5 \%$, good less by $8.1 \%$ as well as the not good criteria as much as $0.8 \%$. Based on the analysis of the data can be concluded, that the percentage of the family environment level of students of the Universitas Negeri Malang in the category of 'excellent', which is $54.6 \%$.

\begin{tabular}{|c|c|c|c|c|}
\hline No & Category & Interval & Frequency & Percentage \\
\hline 1 & Very good & $52-64$ & 208 & $54.6 \%$ \\
\hline 2 & Good & $40-51$ & 139 & $36.5 \%$ \\
\hline 3 & Good less & $28-39$ & 31 & $8.1 \%$ \\
\hline 4 & Not good & $16-27$ & 3 & $0.8 \%$ \\
\hline \multicolumn{3}{|c|}{ Total } & 381 & $100.0 \%$ \\
\hline
\end{tabular}

The environmental level of the UM student family is very good category. This demonstrates the process of transforming knowledge, experience, and self-creation of student characters occurring in a family environment [24], [25]. There are three things that affect the development of a child in his life [25], (1) family functioning, the family function consists of education and socialization functions [24]; (2) parental treatment and attitudes toward children, parents ' behaviour and attitudes toward children are essentially role models for children in their life processes affecting their development, including entrepreneurship intention; and (3) economic status, is considered a factor affecting the development of the child's personality.

\subsection{Students Entrepreneurship Education}

Thus the length of the interval class, frequency distribution, and student entrepreneurship education percentage are defined as in Table 4. Based on Table 4. can be explained that the level of entrepreneurship education of students obtained very good criteria with a percentage of $24.4 \%$, good at $52.2 \%$, good less at $17.1 \%$ as well as not good criteria of $6.3 \%$. Based on the analysis of data can be concluded that the percentage of entrepreneurship education students of the Universitas Negeri Malang in the category of ' good ', which is $52.2 \%$.

Table 4. Frequency Distribution of Student Entrepreneurship Education

\begin{tabular}{clccc}
\hline No & Category & Interval & Frequency & Percentage \\
\hline 1 & Very good & $73-89$ & 93 & $24.4 \%$ \\
2 & Good & $56-72$ & 199 & $52.2 \%$ \\
3 & Good less & $39-55$ & 65 & $17.1 \%$ \\
4 & Not good & $22-38$ & 24 & $6.3 \%$ \\
\hline \multicolumn{2}{r}{ Total } & & 381 & $100.0 \%$ \\
\hline
\end{tabular}


The level of entrepreneurship education of UM students is in good category. This indicates that the entrepreneurship education of UM students has been going well but can be upgraded into very good categories. The implementation of entrepreneurship education in the classroom is an authentic learning process, field experience, consulting project and project where students gain immediate experience about entrepreneurship means value [15]. Increasing the effectiveness of entrepreneurship education or training, university leaders to courses should be able to manage overall entrepreneurship programs by matching specific programs with specific targets [26]. The implementation of good entrepreneurship education must meet the following indicators [27], (1) curriculum, entrepreneurship-based education competencies given to students; (2) The quality of the educators, in this case lecturers as educators not only have to master science, but also must be able to convey the science well to students; (3) The Teaching and learning facility.

\subsection{Students Entrepreneurship Intention}

Thus the length of the interval class, frequency distribution, and student entrepreneurship intention percentage are set out as in Table 5. Based on Table 5. can be explained that the student's entrepreneurship intention rate gained very good criteria with a percentage of $54.3 \%$, good at $37.8 \%$, good less at $6.3 \%$ and not good criteria of $1.6 \%$. Based on the analysis of the data can be concluded, that the percentage of an intention rate entrepreneurship students of the Universitas Negeri Malang in the category of 'excellent', which is $54.3 \%$.

Table 5. Frequency Distribution of Student Entrepreneurship Intention

\begin{tabular}{clccc}
\hline No & Category & Interval & Frequency & Percentage \\
\hline 1 & Very good & $65-80$ & 207 & $54.3 \%$ \\
2 & Good & $50-64$ & 144 & $37.8 \%$ \\
3 & Good less & $35-49$ & 24 & $6.3 \%$ \\
4 & Not good & $20-34$ & 6 & $1.6 \%$ \\
\hline \multicolumn{7}{r}{ Total } & 381 & $100.0 \%$ \\
\hline
\end{tabular}

Based on the results of the study, the intention rate of UM students was in a very good category. Entrepreneurship intention is based on the feeling of delight and the desire to engage in a business [4]. An entrepreneurship intention is defined as someone's desire to start or establish a business owner [28], [29]. Entrepreneurship can be done by running a business on their own or taking advantage of the business opportunities available in the community to realize a new business with a creative and innovative approach [28]. A successful entrepreneur sets out their business objectives and takes timely decisions to achieve that goal in an increasingly competitive and uncertain environment.

\subsection{Students Future Career Planning}

Thus the length of the interval class, frequency distribution, and percentage of future career planning of the student are set out as in Table 6. Based on Table 6. Can be explained that the future career planning level of students of the Universitas Negeri Malang obtained very good criteria with a percentage of $28.1 \%$, good at $60.6 \%$, good less at $10.2 \%$ as well as not good criteria of $1.1 \%$. Based on the analysis of the data can be concluded, that the percentage of the future career planning of students of the Universitas Negeri Malang in the category of ' good ', which is $60.6 \%$. 
Table 6. Frequency Distribution of Students Future Career Planning

\begin{tabular}{clccc}
\hline No & Category & Interval & Frequency & Percentage \\
\hline 1 & Very good & $90-110$ & 107 & $28.1 \%$ \\
2 & Good & $69-89$ & 231 & $60.6 \%$ \\
3 & Good less & $48-68$ & 39 & $10.2 \%$ \\
4 & Not good & $27-47$ & 4 & $1.1 \%$ \\
\hline \multicolumn{7}{r}{ Total } & 381 & $100,0 \%$ \\
\hline \multicolumn{5}{r}{}
\end{tabular}

Based on the research results it is known that the level of future career planning of UM students is in good category. Future career planning is important to be owned by individuals [2], [30]. Fully individual careers under the control of individuals including information collection, problem solving, and decision making. The stage in formulating a career plan consists of four stages, namely: (1) Assessing oneself; (2) Setting a career goal; (3) Prepare plans; and (4) Carry out these plans [31]. The current situation, where graduates of educational institutions have difficulty finding a decent job because of the economic crisis. Career Center services at colleges around the world have introduced entrepreneurship in an effort to promote entrepreneurship and professional entrepreneurship careers [5], [14], [29].

\section{Conclusion}

Successful people usually have a mature career plan early on. But career planning does not guarantee career success, attitude, experience, education, family support, and intention also plays an important role in individual careers. One way to generate successful entrepreneurs needs to be equipped with skills, knowledge, and tips and tricks to make them successful in the future. Based on the research results, formulated recommendations for university leaders, should university leaders can improve the performance of Career center management and formulate policies on entrepreneurship education in the appropriate campus environment in order to increase the intention of entrepreneurship and ideal career plan students in the era of Industrial Revolution 4.0.

\section{Acknowledgements}

The authors would like thank to the Dean Faculty of Education State University of Malang, Indonesia, who has given permission to conduct this research, so that this research can be completed. Special thanks to those who contributed to this article directly or indirectly.

\section{References}

[1] Y. E. Rachmawati, "Hubungan antara Self Efficacy dengan Kematangan Karir pada Mahasiswa Tingkat Awal dan Tingkat Akhir di Universitas Surabaya," Calyptra J. Ilm. Mhs. Surabaya, vol. 1, no. 1, hal. 58-70, 2012.

[2] R. L. Mathis, J. H. Jackson, dan P. A. Meglich, Human Resource Management, 15th Editi. USA: Thomson South-Western, 2017.

[3] J. A. Athanasou dan H. N. Perera, International Handbook of Career Guidance, 2nd Editio. New York: Springer, 2019.

[4] E. Kallas, "Environment-Readiness Entrepreneurship Intention Model: The Case of Estonians and the Russian-Speaking Minority in Estonia," SAGE Open, vol. 9, no. 1, hal. 1-15, 2019, doi: 
$10.1177 / 2158244018821759$.

[5] K. Yildiz, "The Effect of Career Decisions on Entrepreneurial Intention Levels of University Students Studying Sport Sciences," J. Educ. Train. Stud., vol. 6, no. 4a, hal. 13-18, 2018, doi: 10.11114/jets.v6i4a.3112.

[6] A. Stadler dan A. M. J. Smith, "Entrepreneurship in Vocational Education," J. Ind. High. Educ., vol. 31, no. 2, hal. 81-89, 2017, doi: 10.2478/dcse-2018-0003.

[7] A. Al Mamun, N. B. C. Al Nawi, M. Mohiuddin, dan S. F. F. B. Shamsudin, "Entrepreneurial Intention and Startup Preparation: a Study among Business Student in Malaysia," J. Educ. Bus., vol. 68 , no. 4, hal. 296-314, 2017.

[8] L. Sharma, "Impact of Family Capital \& Social Capital on Youth Entrepreneurship," J. Glob. Entrep. Res., vol. 4, no. 14, hal. 1-18, 2014.

[9] A. Alhaji, "Entrepreneurship Education And Its Impact On Self Employment Intention And Entrepreneurial Self-Efficacy," J. Humanit. Soc. Sci., vol. 3, no. 1, hal. 57-63, 2015.

[10] A. Abdelkarim, "Toward Establishing Entrepreneurship Education and Training Programmes in a Multinational Arab University," J. Educ. Train. Stud., vol. 7, no. 1, hal. 1-9, 2019, doi: 10.11114/jets.v7i1.3833.

[11] Renny, R. Chandra, S. Ruhama, dan M. W. Sarjono, "Exploring Indonesian Web Based Career Center," UACEE Int. J. Adv. Comput. Sci. its Appl., vol. 3, no. 2, hal. 212-216, 2013.

[12] J. Memon, M. Z. A. Rozan, K. Ismail, M. Uddin, dan D. K. Daud, "Mentoring an Entrepreneur: Guide for a Mentor," SAGE Open, vol. 5, no. 1, hal. 1-10, 2015, doi:

$10.1177 / 2158244015569666$.

[13] S. G. Walter dan J. H. Block, "Outcomes of Entrepreneurship Education: An Institutional Perspective," J. Bus. Ventur., vol. 31, no. 2, hal. 216-233, 2016.

[14] G. Nabi, F. Linan, A. Fayolle, N. Krueger, dan A. Walmsley, "The Impact of Entrepreneurship Education in Higher Education: A Systematic Review and Research Agenda," Acad. Manag. Learn. Educ., vol. 16, no. 2, hal. 277-299, 2017, doi: 10.5465/amle.2015.0026.

[15] H. Y. Foo dan J. J. Turner, “"Entrepreuneurial Learning' The Role of Universitiy Led Business Incubators and Mentors in Equipping Graduates with the Necessary Skills Set for Industry 4.0," Int. J. Educ. Psychol. Couns., vol. 4, no. 30, hal. 283-298, 2019.

[16] B. B. Wiyono, Metodologi Penelitian (Pendekatan Kuantitatif, Kualitatif, dan Action Research). Malang: FIP Universitas Negeri Malang, 2007.

[17] J. C. Creswell, Research Design: Qualitative, Quantitative, and Mixed Methods Approaches, 4 Edition. London: Sage Publications, 2014.

[18] LP3 UM, "Visi Misi P2BK3A," 2019. [Daring]. Tersedia pada: http://lp3.um.ac.id/index.php/visi-misi-p2bk3a/. [Diakses: 02-Feb-2020].

[19] Kemenristekdikti, Buku Panduan Pusat Karir. Jakarta: Tim Kementerian Riset Teknologi Dan Perguruan Tinggi RI, 2016.

[20] Widyastuti, Pusat Karir \& Kewirausahaan Mahasiswa ITS PTNBH (Menuju Career Center World Class University). Surabaya: ITS Press, 2018.

[21] H. Arasteh, T. Enayati, F. Zameni, dan A. Khadembo, "Entrepreneurial Personality Characteristics of University Students: A Case Study," Procedia-Soc. Behav. Sci., vol. 46, hal. 5736-5740, 2012.

[22] L. Kozubikova, J. Dvorsky, M. Cepel, dan A. P. Balcerzak, "Important Characteristics of an Entrepreneur in Relation to Risk Taking: Czech Republic Case Study," J. Int. Stud., vol. 10, no. 3, hal. 220-233, 2017, doi: 10.14254/2071- 8330.2017/10-3/16.

[23] W. G. Nickels, Understanding Business, 10th Editi. New York: McGraw Hill, 2012.

[24] T. Shen, A. E. Osorio, dan A. Settles, "Does Family Support Matter? The Influence of Support Factors on Entrepreneurial Attitudes and Intentions of College Students," Acad. Entrep. J., vol. 23, no. 1, hal. 24-43, 2017.

[25] C. Semiawan, Pendidikan Keluarga Dalam Era Global. Jakarta: PT. Preenhallindo, 2010.

[26] D. Matricano, "Can Policymakers Improve the Effectiveness of Entrepreneurship Training Programmes? Evidence from Italy," J. Ind. High. Educ., vol. 31, no. 1, hal. 51-61, 2017, doi: $10.1177 / 0950422216684071$. 
[27] A. Munib, Pengantar Ilmu Pendidikan. Semarang: UNNES, 2010.

[28] J. C. A. Calvo dan G. M. García, "Established Business Owners' Success: Influencing Factors," J. Dev. Entrep., vol. 15, no. 03, hal. 263-286, 2010, doi: 10.1142/S1084946710001555.

[29] A. I. Vodă dan N. Florea, "Impact of Personality Traits and Entrepreneurship Education on Entrepreneurial Intentions of Business and Engineering Students," Sustain., vol. 11, no. 4, hal. 1-34, 2019, doi: 10.3390/SU11041192.

[30] L. W. Rue, N. A. Ibrahim, dan L. L. Byars, Human Resource Management, 11 th editi. Chicago: The Mc.Graw-Hill Companies, Inc, 2016.

[31] D. Ozora, L. Suharti, dan H. Sirine, "Potret Perencanaan Karir Pada Mahasiswa," in Prosiding Seminar Nasional Multi Disiplin Ilmu \& Call For Papers Unisbank (SENDI_U) ke 2, 2016, hal. 623-632. 